\title{
The effects of iron deficiency and iron overload on cell-mediated immunity in the mouse
}

\author{
BY FELIX O. OMARA AND BARRY R. BLAKLEY* \\ Department of Veterinary Physiological Sciences, Western College of Veterinary Medicine, \\ University of Saskatchewan, Saskatoon S7N 0W0, Canada
}

(Received 25 January 1994 - Revised 24 March 1994 - Accepted 10 May 1994)

\begin{abstract}
The influence of Fe status on cell-mediated immunity was studied in weanling mice fed on Fe-deficient ( $7 \mathrm{mg} \mathrm{Fe} / \mathrm{kg}$ ), Fe-sufficient ( $120 \mathrm{mg} \mathrm{Fe} / \mathrm{kg}$ ) and high-Fe (3000 or $5000 \mathrm{mg} \mathrm{Fe} / \mathrm{kg}$ ) diets for 7 weeks. The contact sensitivity (CS) response to dinitrofluorobenzene (DNFB), the in vivo delayed-type hypersensitivity (DTH) response to sheep erythrocytes (SRBC) and the ability of primed spleen cells to transfer DTH response to naive normal mice were suppressed in mice consuming the Fe-deficient diet. High-Fe diets ( 3000 or $5000 \mathrm{mg} \mathrm{Fe} / \mathrm{kg}$ ) selectively suppressed the CS response to DNFB, but the DTH response to SRBC or the transfer of DTH response by primed spleen cells to naive normal mice remained normal. Spleen cell functions associated with the expression of class II major histocompatibility (MHC) surface antigens, concanavalin A-induced interleukin-2 (IL-2) secretion or the antigen-presenting cell (APC) ability to stimulate antigen-dependent proliferation of an SRBC-specific helper T-lymphocyte clone were not altered by Fe status. However, consistent with the suppressed DTH response in the Fedeficient mice was the suppressed concanavalin $A$-induced $T$-lymphocyte blastogenesis and the interferon- $\gamma$ (INF- $\gamma$ ) production by spleen cells from mice fed on the Fe-deficient diet. Spleen cells from mice fed on excess levels of Fe in the diet secreted less INF- $\gamma$ than the control mice, although Tlymphocyte proliferation remained unaffected. Suppression of the cellular immune response associated with Fe deficiency may be related in part to impaired T-lymphocyte proliferation and INF- $\gamma$ secretion rather than to deficits in IL-2 secretion or APC function.
\end{abstract}

Immune function: Iron deficiency: Iron overload

Fe status influences immune function. Previous investigations have reported alterations in the cell-mediated immune (CMI) response in Fe-deficient or Fe-loaded human patients (Joynson et al. 1972; MacDougall et al. 1975; Dwyer et al. 1987). The delayed-type hypersensitivity (DTH) response, a classical CMI response, is the primary defence against certain intracellular infections such as mycobacteria (Abbas et al. 1991). A reduction in immune competence by $\mathrm{Fe}$ deficiency or excess $\mathrm{Fe}$ might lead to an increased susceptibility of the host to infection.

Confounding variables in clinical studies, such as additional nutritional deficiencies or pre-existing infection, make it difficult to conclude that $\mathrm{Fe}$ is the only causative factor in the immune alterations. Some reports also disagree about the effect of Fe deficiency or overload on CMI (Joynson et al. 1972; Chandra, 1975; Van Asbeck et al. 1982). The only animal experiment supporting the human findings is the suppression of contact sensitivity (CS) response to dinitrofluorobenzene (DNFB; Kuvibidila et al. 1981). Although CS response is often employed as a measure of CMI and, thus, the DTH response, experimental evidence indicates that the induction of CS response also requires the participation of immunoglobulin E (IgE) antibody (Ray et al. 1983).

Precisely how $\mathrm{Fe}$ alters the CMI response is poorly defined. Induction of the DTH

* For reprints 
response is mediated by antigen-specific T-lymphocytes (usually of the CD4 $4^{+}$phenotype) which recognize peptide-derived antigen in association with the class II major histocompatibility complex (MHC) molecules on the surface of antigen-presenting cells (APC) such as macrophages. The activated $T_{\mathrm{DTH}}$-lymphocytes then secrete interleukin-2 (IL-2) and stimulate effector cells which secrete biologically active lymphokines such as interferon$\gamma($ INF- $\gamma$ ) which recruit and activate phagocytic cells to eliminate the antigen (Dovrak et al. 1986; Heinzel et al. 1989). IL-2 is the principal T-lymphocyte growth factor which promotes the proliferation of T-lymphocytes (Smith, 1984). INF- $\gamma$ is a potent macrophageactivating lymphokine and an important mediator of the DTH response and cellular cytotoxicity which are critical for defence against intracellular pathogens and viruses (Flesch \& Kaufmann, 1987).

In the present study the effect of subclinical Fe deficiency or Fe overload on CMI using the in vivo CS response to DNFB and the in vitro and in vivo DTH responses to sheep erythrocytes (SRBC) was studied. To identify the possible cellular mechanisms associated with the altered CMI response induced by Fe status the APC function of splenic macrophages and T-lymphocyte function such as proliferation and secretion of IL-2 or INF- $\gamma$ were evaluated.

\section{MATERIALS AND METHODS \\ Mice}

Male CD-1 (Charles River, Montreal, PQ, Canada), Balb/c (Animal Resources Centre, University of Saskatchewan, Saskatoon, Canada) or CBA/J mice were randomly allocated to each diet group at 3 weeks of age. Adult male CD-1 mice (7-8 weeks old; Animals Resources Centre, University of Saskatchewan) used for the DTH transfer experiments were fed on a certified rodent pelleted diet (Prolab Rat, Mouse, Hamster 3000 Formula; Agway Country Foods, Syracuse, NY, USA). The mice received the appropriate diet and distilled, deionized water ad lib. for 7 weeks.

Diets

The experiment diet contained $(\mathrm{g} / \mathrm{kg}$ ) casein 200 , dextrose 683 , maize oil $50, \alpha$-cellulose 10 , vitamin mixture 22 , Fe-free mineral mixture 35 , and was a modification of the diet described previously by Blakley \& Hamilton (1988). Analysis by atomic absorption spectroscopy revealed the diet contained $7 \mathrm{mg} \mathrm{Fe} / \mathrm{kg}$ and was identified as the Fe-deficient diet. $\mathrm{FeSO}_{4} .7 \mathrm{H}_{2} \mathrm{O}$ (BDH Chemicals, Toronto, Canada) was added to the basal diet to provide $120 \mathrm{mg} \mathrm{Fe} / \mathrm{kg}$ for the control diet (Sorbie \& Valberg, 1975), 3000 or $5000 \mathrm{mg} \mathrm{Fe} / \mathrm{kg}$ for the Fe-loaded diets. Diets were prepared weekly and stored in sealed portions in the dark at $-4^{\circ}$ to avoid rancidity. The certified Prolab rodent diet used in the transfer studies contained the following ingredients $(\mathrm{g} / \mathrm{kg})$ : protein 220 , carbohydrate 616 , fat 55 , fibre 50 , vitamin mixture 23 and essential minerals 36 . The concentration of $\mathrm{Fe}$ in the diet was $289 \mathrm{mg} / \mathrm{kg}$.

\section{Measurement of immune competence}

Tests of immune competence included in vivo CS response to DNFB and the in vivo and in vitro DTH responses to SRBC. In addition, APC function of spleen cells, expression of class II MHC surface antigens, splenocyte proliferation and the IL-2 or INF- $\gamma$ secretion on activation by concanavalin $\mathrm{A}$ (Con $\mathrm{A}$ ), a T-lymphocyte mitogen, were evaluated. All tests were initiated after the mice had been fed on the experimental diets for 7 weeks.

In vivo contact sensitivity response

CS was induced following the application of $500 \mu \mathrm{g}$ DNFB (Sigma Chemical Co., St Louis, MO, USA) in $30 \mu \mathrm{l}$ of an acetone-olive oil $(1: 1, \mathrm{v} / \mathrm{v})$ mixture onto the shaved abdomen of 
the CD-1 mice (ten mice per treatment group). After $5 \mathrm{~d}, 100 \mu \mathrm{g}$ DNFB in $20 \mu \mathrm{l}$ acetone-olive oil was applied to both sides of the left ear of the mice, while the right ear served as a negative control and received the vehicle only. After $24 \mathrm{~h}$ the mice received $2 \mu \mathrm{Ci}$ ${ }^{125}$ I-labelled deoxyuridine $\left({ }^{125} \mathrm{I}\right.$-dUR; specific activity $2000 \mathrm{Ci} / \mathrm{mmol}$; ICN Biomedicals Inc, Mississauga, Ontario, Canada) in $0.2 \mathrm{ml}$ saline $(9 \mathrm{~g} \mathrm{NaCl} / 1)$ given intraperitoneally. The mice were killed after $24 \mathrm{~h}$ by cervical dislocation, the ears were removed and radioactivity was measured in a gamma-counter (Apex Automatic Counter Model no. 28022; ICN Micromedic Systems, Horsham, PA, USA). The in vivo incorporation of the DNA precursor ${ }^{125} \mathrm{I}$-dUR is used as an index of the CS response (Vadas et al. 1975). The amount of radioactivity (counts/min; cpm) incorporated was expressed as ratio of activity in left ear:activity in right ear and was used as a measure of the CS response.

\section{In vivo delayed-type hypersensitivity response}

The DTH response was induced in the CD-1 mice using a single intravenous injection of $0.2 \mathrm{ml}$ washed SRBC suspension in phosphate-buffered saline (PBS; $0.1 \mu 1 / \mathrm{ml}$ ). The mice were challenged $4 \mathrm{~d}$ later by injection into the left hind footpad with $20 \mu 1$ SRBC in PBS $(200 \mathrm{ml} / 1)$. The right hind footpad was injected with $20 \mu 1$ PBS as a negative control. Footpad swelling was measured using a calliper (Oditest, Kraeplain, Germany) $24 \mathrm{~h}$ after challenge. The difference in footpad thickness between the SRBC- and non-SRBC-injected footpads, which was expressed in units where one unit is equivalent to $0.01 \mathrm{~mm}$, was used as a quantitative measure of the DTH response (Bretscher, 1979).

\section{In vitro delayed-type hypersensitivity response and transfer studies}

In vitro studies were conducted for comparison with the in vivo studies and to identify the cellular alteration in CMI function induced by Fe status. The method has been previously described by Bretscher (1979). Balb/c mice (five mice per group) consuming the experimental diets for 7 weeks were injected intravenously with $0.2 \mathrm{ml}$ washed SRBC in PBS ( $1 \mu \mathrm{l} / \mathrm{ml}$; study 1$)$. In study 2 , five adult Balb/c mice consuming the standard rodent diet were injected with $0.2 \mathrm{ml} \mathrm{SRBC}$ suspension $(1 \mu \mathrm{l} / \mathrm{ml})$. After $2 \mathrm{~d}$ the mice in each group were killed, spleens removed and spleen-cell suspensions were prepared by teasing the spleens gently with sterile forceps. In each study, pooled spleen-cell suspensions were washed in RPMI 1640 (Gibco, Grand Island, NY, USA). The erythrocytes were lysed using $\mathrm{NH}_{4} \mathrm{Cl}$ in $0.01 \mathrm{M}$-Tris- $\mathrm{HCl}(8.3 \mathrm{~g} / 1), \mathrm{pH} 7.3$ (Sigma Chemical Co.). The cells were suspended in RPMI supplemented with fetal bovine serum $(100 \mu 1 / \mathrm{ml}$; FBS), $50 \mu$ g streptomycin $/ \mathrm{ml}$ and 50 units penicillin $/ \mathrm{ml}$ (Gibco). The splenic white cells were cultured at $1 \times 10^{7}$ cells per well in six-well plates (Costar, Cambridge, MA, USA) in $8 \mathrm{ml}$ supplemented RPMI medium plus $50 \mu \mathrm{l} \mathrm{SRBC}$ in RPMI medium $(100 \mu \mathrm{l} / \mathrm{ml})$ for $6 \mathrm{~d}$ at $37^{\circ}$ in $\mathrm{CO}_{2}(50 \mathrm{ml} / \mathrm{l})$ to generate primed spleen cells with DTH reactivity (Bretscher, 1979).

After $6 \mathrm{~d}$ the cells were harvested and washed in RPMI medium. Dead cells and SRBC were removed from the suspension using the lymphocyte-M technique as outlined by Cedarlane Laboratories Ltd (Hornby, Ontario, Canada). Briefly, up to $1 \times 10^{7}$ viable cultured splenic leucocytes were suspended in $5 \mathrm{ml}$ RPMI medium and loaded on top of $5 \mathrm{ml}$ lymphocyte-M medium in a $15 \mathrm{ml}$ plastic centrifuge tube which was centrifuged at $1000 \mathrm{~g}$ for $20 \mathrm{~min}$ at room temperature. The viable spleen cells were harvested from the liquid interface and washed twice in RPMI medium. The primed spleen cells free of antigen (SRBC) were injected into the left hind footpad of the appropriate syngeneic age-matched recipient male Balb/c mice (study 1 and study 2) either with or without the SRBC antigen. The primed spleen cells and the antigen were mixed together to produce a cell pellet containing $1 \times 10^{7}$ viable primed spleen cells in $1 \mathrm{ml}$ RPMI plus $50 \mu \mathrm{l}$ SRBC in RPMI 
(100 $\mu \mathrm{l} / \mathrm{ml}$ ), which was suspended in $20 \mu 1$ RPMI medium and injected into the footpads of appropriate recipient naive mice. Control recipient mice were injected with $1 \times 10^{7}$ primed spleen cells in $20 \mu \mathrm{l}$ RPMI medium. In study 1, primed spleen cells from each experimental diet group were injected into footpads of adult age-matched naive male $\mathrm{Balb} / \mathrm{c}$ mice fed on standard commercial pelleted rodent diet (ten mice per group). In study 2 , primed spleen cells generated from normal mice were injected into footpads of agematched naive male Balb/c mice from each dietary Fe treatment group (ten mice per group). The footpad thickness was measured after $24 \mathrm{~h}$ as described previously (in vivo DTH response). The ability of the primed spleen cells to cause swelling when injected with the antigen is associated with T-lymphocytes and reflects the DTH response (Bretscher, 1979).

\section{T-lymphocyte blastogenesis}

Pooled splenic white cells (five Balb/c mice per group) from each experimental $\mathrm{Fe}$ diet treatment group were plated in ninety-six-well flat-bottom Costar (Cambridge, MA, USA microtitre plates $\left(2 \times 10^{5}\right.$ cells per well) in a total of $200 \mu \mathrm{l}$ supplemented RPMI medium containing $2.5 \mu \mathrm{g}$ Con A $/ \mathrm{ml}$, a T-lymphocyte mitogen. The cultures were incubated for $48 \mathrm{~h}$ at $37^{\circ}$ in $\mathrm{CO}_{2}\left(50 \mathrm{ml} / 1\right.$ air) and $0.5 \mu \mathrm{Ci}\left[{ }^{3} \mathrm{H}\right]$ thymidine (specific activity $6.7 \mathrm{Ci} / \mu \mathrm{mol}$; New England Nuclear, Boston, MA, USA) in $25 \mu 1$ RPMI medium was added $8 \mathrm{~h}$ before the end of the incubation period. The cells were harvested with an automated cell harvester (Skatron, Lier, Norway). The filter disks were dried and added to vials containing $3 \mathrm{ml}$ Ready Safe scintillation fluid (Beckman LS38000; Beckman, Mississauga, Ontario, Canada). The cultures were run in triplicate with eight determinations per group and the results were expressed as a stimulation index (i.e. ratio of the radioactivity $(\mathrm{cpm})$ in mitogen-stimulated cultures: non-stimulated background radioactivity (cpm).

\section{Interleukin-2 and interferon- $\gamma$ production}

Pooled splenic white cells (five Balb/c mice per experimental Fe diet treatment group) were cultured at $1 \times 10^{6}$ cells per well in ninety-six-well flat-bottom Costar Plates in $200 \mu 1$ supplemented RPMI with or without Con A $(2.5 \mu \mathrm{g} / \mathrm{ml})$. The cells were incubated at $37^{\circ}$ in $\mathrm{CO}_{2}(50 \mathrm{ml} / 1$ air) for 24 and $48 \mathrm{~h}$ for IL-2 and INF- $\gamma$ production respectively. The plates were centrifuged and the supernatant fractions were collected and the triplicate supernatant fractions were pooled and stored at $-70^{\circ}$ for IL-2 or INF- $\gamma$ analysis. The IL-2 or INF- $\gamma$ levels were quantified with a commercial mouse IL-2 or INF- $\gamma$ ELISA kit (Genzyme, Cambridge, MA, USA) following the manufacturer's specifications.

\section{Antigen-presenting cell function}

Two aspects of the APC function were evaluated: the APC ability and the expression of the class II MHC surface antigen by spleen cells from mice fed on the experimental Fe diets for 7 weeks. Pooled splenic white cells (six Balb/c mice per diet group) were suspended in Facola medium (Sigma Chemical Co.) containing $2 \times 10^{7}$ cells $/ \mathrm{ml}$. Then $1 \times 10^{6}$ cells in $20 \mu 1$ Facola media were added per well in ninety-six well U-bottom microtitre Immunonlon plates (Dynatech Laboratories, Chantilly, VA, USA). Fluorescein-conjugated anti-mouse I-A monoclonal antibody $(50 \mu \mathrm{l} ; 1: 200$ dilution in Facola medium containing $100 \mathrm{ml}$ normal fresh mouse serum/l) was added into each well. The plates were incubated on ice in the dark for $30 \mathrm{~min}$, washed and suspended in $200 \mu$ l formaldehyde in PBS $(20 \mathrm{ml} / \mathrm{l})$ and stored at $4^{\circ}$ wrapped in $\mathrm{Al}$ foil until analysis with a flow cytometer. The flow cytometer (Epics Division of Coulters Corporation, Hialeah, FL, USA) with excitation at $488 \mathrm{~nm}$ using a $2 \mathrm{~W}$ Ar laser was adjusted to select splenic macrophages from the cell population to detect the expression of class II MHC antigen. 
The APC activity was evaluated using pooled spleen cells (four CBA/J mice per diet group) from CBA/J mice fed on the experimental Fe diets for 7 weeks. An SRBC-specific T-helper lymphocyte clone (kindly provided by Jim Holmstrom, Department of Microbiology, University of Saskatchewan, Saskatoon, Canada) derived from CBA/J mouse spleen cells was used to evaluate the APC activity. The splenic white cells used as a source of APC were irradiated at $1500 \mathrm{Rad}$ from a ${ }^{60} \mathrm{Co}$-gamma source, Gamma-cell 200 (Atomic Energy of Canada Ltd, Ottawa, Ontario, Canada). The helper T-lymphocyte clone cells $\left(1 \times 10^{4}\right)$ were cultured with $1 \times 10^{6}$ irradiated spleen cells from each dietary group in triplicate from eight cultures in $200 \mu 1$ supplemented RPMI medium plus $10 \mu 1$ washed SRBC $(10 \mathrm{ml} / \mathrm{l})$ per well in ninety-six-well Costar plates. The cultures were incubated for $72 \mathrm{~h}$ at $37^{\circ}$ in $\mathrm{CO}_{2}\left(50 \mathrm{ml} / 1\right.$ air) and $0.5 \mu \mathrm{Ci}\left[^{3} \mathrm{H}\right]$ thymidine in $25 \mu 1 \mathrm{RPMI}$ medium was added to each well $8 \mathrm{~h}$ before harvesting with the automatic cell harvester as described in the section for T-lymphocyte proliferation. The results were expressed as increased $\mathrm{cpm}$ $(\Delta \mathrm{cpm})$ above the non-antigen (SRBC)-stimulated control cultures.

\section{Determination of the liver iron concentrations}

About $1 \mathrm{~g}$ liver was digested in a mixture of concentrated $\mathrm{HNO}_{3}, \mathrm{HClO}_{3}$ and $\mathrm{H}_{2} \mathrm{SO}_{4}(5: 1: 1$, by vol.) using a programmed block digestor (Tecator digestion system model 1015; Tecator, Hoganas, Sweden). The liver samples were diluted to appropriate volumes with double-distilled, deionized water and analysed for the $\mathrm{Fe}$ content by flame atomic absorption spectrophotometer (Perkin-Elmer Model 2380 AA).

\section{Statistical analysis}

Treatment means, standard error of means, one-way analysis of variance and Fisher protracted least-significance difference test $(P<0.05)$ were determined by the statistical software StatWork (Brain Power Inc., Calabasas, CA, USA).

\section{RESULTS}

\section{Body weights and iron status}

Fe-deficient mice were characterized by markedly lower concentrations of $\mathrm{Fe}$ in the liver whereas consumption of high-Fe diets caused marked accumulation $(P<0.0001)$ of $\mathrm{Fe}$ in the liver (Table 1). However, body weight gain and packed cell volume were not different among the diet groups (values not shown).

In vivo contact sensitivity and delayed-type hypersensitivity studies

Mice fed on the Fe-deficient and high-Fe diets were less responsive to sensitization with DNFB $(P<0.0001)$ than mice fed on the normal-Fe diet (Fig. 1(a)). The incorporation ratio of ${ }^{125} \mathrm{I}$-dUR into both ears, which is an index of the CS response, was reduced by 45 , 52 and $45 \%$ in mice fed on the Fe-deficient and the two high-Fe diets respectively.

The results for the classical DTH response to SRBC, a protein antigen, are shown in Fig. 1(b). The Fe-deficient mice were less responsive to sensitization with the SRBC antigen $(P<0.0001)$. Sensitization in the two Fe-supplemented groups of mice was similar to the response in Fe-sufficient mice. The Fe-deficient mice exhibited a weak reaction which was $44 \%$ of the response in mice fed on the Fe-sufficient diet. Non-specific swelling caused by injection of SRBC into the footpads of unprimed control mice ranged from 0.4 to 0.8 units indicating that previous sensitization with $\mathrm{SRBC}$ was required to produce the DTH response. 
Table 1. Liver concentrations of iron in strains of mice fed on iron-deficient, iron-sufficient and high-iron diets*

(Mean values with their standard errors for no. of animals shown)

\begin{tabular}{|c|c|c|c|c|c|c|}
\hline \multirow{3}{*}{$\begin{array}{c}\text { Dietary } \mathrm{Fe} \\
\text { concentration }(\mathrm{mg} / \mathrm{kg})\end{array}$} & \multicolumn{6}{|c|}{ Hepatic Fe concentrations $(\mu \mathrm{mol} / \mathrm{g})$ in different mouse strains } \\
\hline & \multicolumn{2}{|c|}{ CD-1 mouse ( $n$ 6) } & \multicolumn{2}{|c|}{ Balb/c mouse $(n 6)$} & \multicolumn{2}{|c|}{ CBA /J mouse $(n 4)$} \\
\hline & Mean & $\mathrm{SE}$ & Mean & SE & Mean & SE \\
\hline 7 & $1.8^{a}$ & $0 \cdot 2$ & $1 \cdot 5^{\mathrm{a}}$ & $0 \cdot 1$ & $1 \cdot 7^{\mathrm{u}}$ & 0.3 \\
\hline 120 & $3 \cdot 0^{\mathrm{b}}$ & 0.1 & $2 \cdot 9^{b}$ & 0.2 & $3 \cdot 1^{b}$ & 0.2 \\
\hline 3000 & $13 \cdot 8^{\mathrm{c}}$ & $0 \cdot 3$ & $14 \cdot 0^{\mathrm{c}}$ & $0 \cdot 3$ & $15 \cdot 3^{\mathrm{c}}$ & 0.2 \\
\hline 5000 & $20 \cdot 1^{d}$ & 0.2 & $19 \cdot 2^{d}$ & $0 \cdot 2$ & $21 \cdot 5^{\mathrm{d}}$ & $0 \cdot 3$ \\
\hline
\end{tabular}

a,b, c,d Values in vertical columns with unlike superscript letters were significantly different $(P<0.05)$.

* For details of animals, diets and procedures, see p. 900 and p. 903.
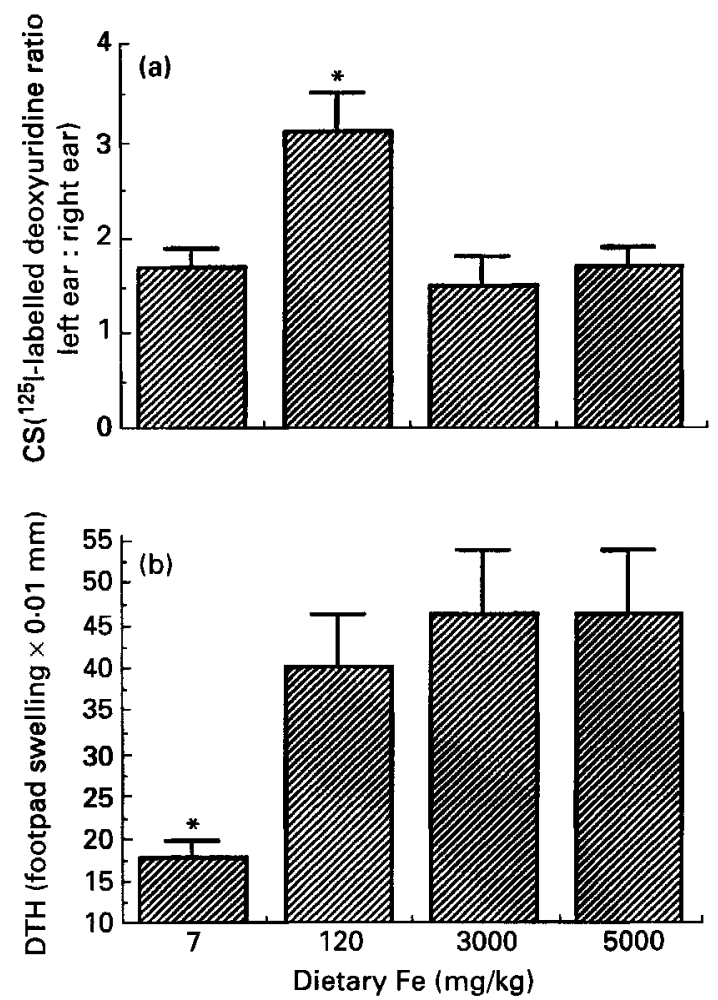

Fig. 1. (a) Contact sensitivity (CS) response to dinitrofluorobenzene and (b) delayed-type hypersensitivity (DTH) response to sheep erythrocytes in male CD-1 mice fed on iron-deficient, iron-sufficient and high-iron diets. Values are means with their standard errors represented by vertical bars for ten mice. Mean value was significantly different from those for other treatments: ${ }^{*} P<0-05$. For details of animals, diets and procedures, see pp. 900-901.

In vitro delayed-type hypersensitivity studies

Fig. 2(a and b) illustrates the response when primed spleen cells generated in culture were assayed for DTH reactivity. Maximal footpad swelling was dependent on the presence of the primed spleen cells and antigen (SRBC) in the footpad. Primed spleen cells generated 


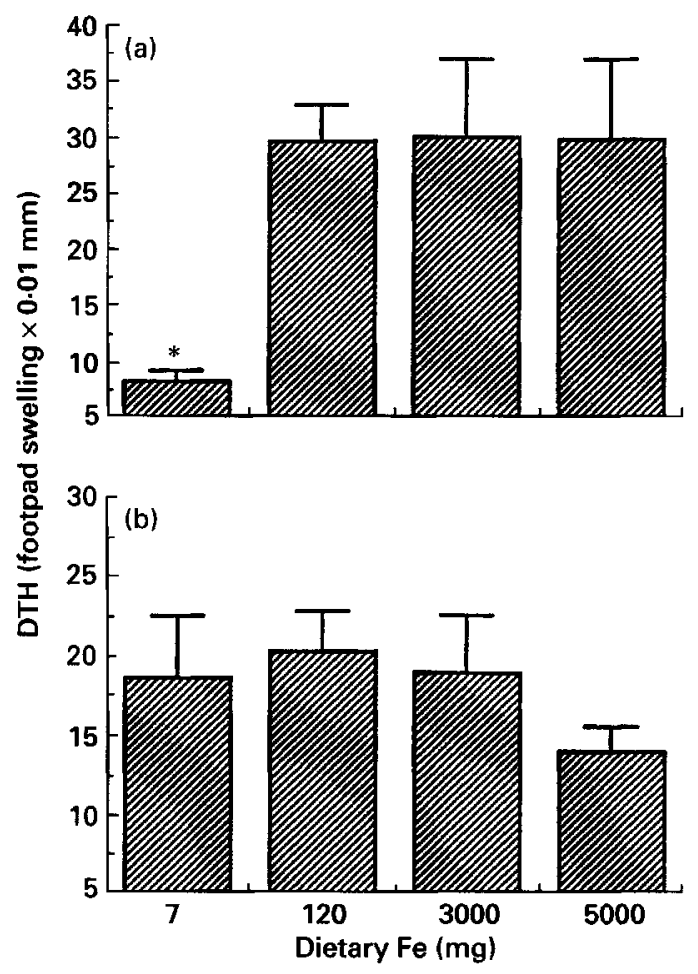

Fig. 2. Adoptive transfer of delayed-type hypersensitivity (DTH) response by (a) primed splenocytes from Balb/c mice fed on iron-deficient, iron-sufficient and high-iron diets in naive normal mice and (b) primed splenocytes from normal mice to induce the DTH response in naive Balb/c mice fed on the experimental diets. Values are means with their standard errors represented by vertical bars for ten mice. Mean value was significantly different from those for other treatments: ${ }^{*} P<0.05$. For details of animais, diets and procedures, see pp. 900902 .

from Fe-deficient mice induced the weakest DTH reaction on injection with antigen into the footpad of naive mice fed on standard rodent commercial diet (Fig. 2(a)), which was $58 \%$ of the response of primed spleen cells from animals fed on the Fe-sufficient experimental diet $(P<0.0001)$. In contrast, there were no significant differences $(P>0.05)$ between the DTH reactions induced by primed spleen cells generated from mice fed on higher levels of $\mathrm{Fe}$ in the diet and the mice fed on the Fe-sufficient experimental diet (Fig. 2(a)). The results of the in vitro DTH adoptive transfer experiments were thus consistent with the in vivo DTH response to SRBC (Fig. 1(b)). The background response, which is a footpad swelling produced by injection of primed spleen cells only, ranged from 1.4 to 1.9 units.

Fig. 2(b) summarizes the adoptive transfer of the DTH response by primed spleen cells generated from mice fed on the Fe-sufficient standard rodent diet into footpads of naive mice fed on the experimental Fe-deficient, Fe-sufficient or Fe-loaded diets. There were no differences among mice from the dietary groups following injection of the normal primed spleen cells with SRBC into the footpads of the mice in the four experimental Fe diet treatment groups $(P>0 \cdot 3706)$.

\section{T-lymphocyte function}

The proliferation of spleen cells induced by the T-lymphocyte mitogen Con A, expressed as a stimulation index, shows that the mice fed on the Fe-deficient diet had lower $\mathrm{T}$ lymphocyte blastogenesis $(P<0.0001)$ than those on the other diets (Fig. 3(a)). The 

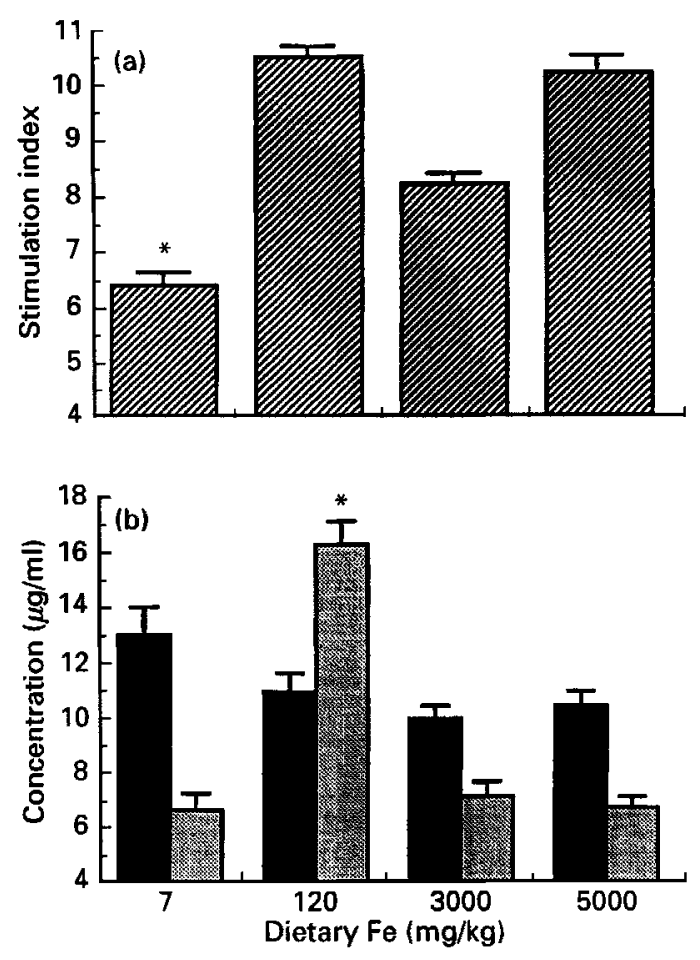

Fig. 3. (a) T-lymphocyte blastogenesis $(\square)$ and (b) interleukin 2 ( $\square$ ) and interferon- $\gamma$ (圈) production by splenocytes from male Balb/c mice fed on iron-deficient, iron-sufficient and high-iron diets. (a) Values represent triplicates of eight determinations in which pooled cells were used $(n$ 5) and (b) values represent duplicates of eight determinations in which pooled cells were used $(n 5)$ with their standard errors represented by vertical bars. Mean value was significantly different from those for other treatments; ${ }^{*} P<0 \cdot 05$. For details of animals, diets and procedures, see p. 900 and p. 902.

stimulation index for mice fed on $3000 \mathrm{mg} \mathrm{Fe} / \mathrm{kg}$ diet was lower than the corresponding values for mice fed on the 120 and $5000 \mathrm{mg} \mathrm{Fe} / \mathrm{kg}$ diets, but was not statistically different. A high background response in the unstimulated spleen cell cultures from the mice fed on $3000 \mathrm{mg} \mathrm{Fe} / \mathrm{kg}$ diet accounted for this discrepancy. Fig. 3(b) shows that there were no differences among the dietary groups in IL-2 production by spleen cells $(P>0.070)$. In contrast, spleen cells from mice fed on the Fe-deficient or high-Fe diets produced less INF$\gamma(P<0.0001)$ than those fed on the Fe-sufficient diet (Fig. 3(b)). Background IL-2 or INF$\gamma$ production by spleen cells was not stimulated with Con A, and was less than $20 \mathrm{pg} / \mathrm{ml}$ in each instance.

\section{Antigen-presenting cell $(A P C)$ function studies}

The APC activity of the irradiated spleen cells (source of APC) to stimulate antigendependent proliferation of the helper T-lymphocyte clone (Fig. 4(a)) shows that there were no differences between the dietary Fe treatment groups $(P>0 \cdot 260)$. The binding pattern of anti-class II MHC antibody adjusted to select splenic macrophages is shown in Fig. 4(b). No differences in the intensity of the fluorescein staining for the class II MHC cell-surface antigen were observed in the treatment groups. The results indicate that APC function was not altered by the consumption of the Fe-deficient or Fe-supplemented diets. 

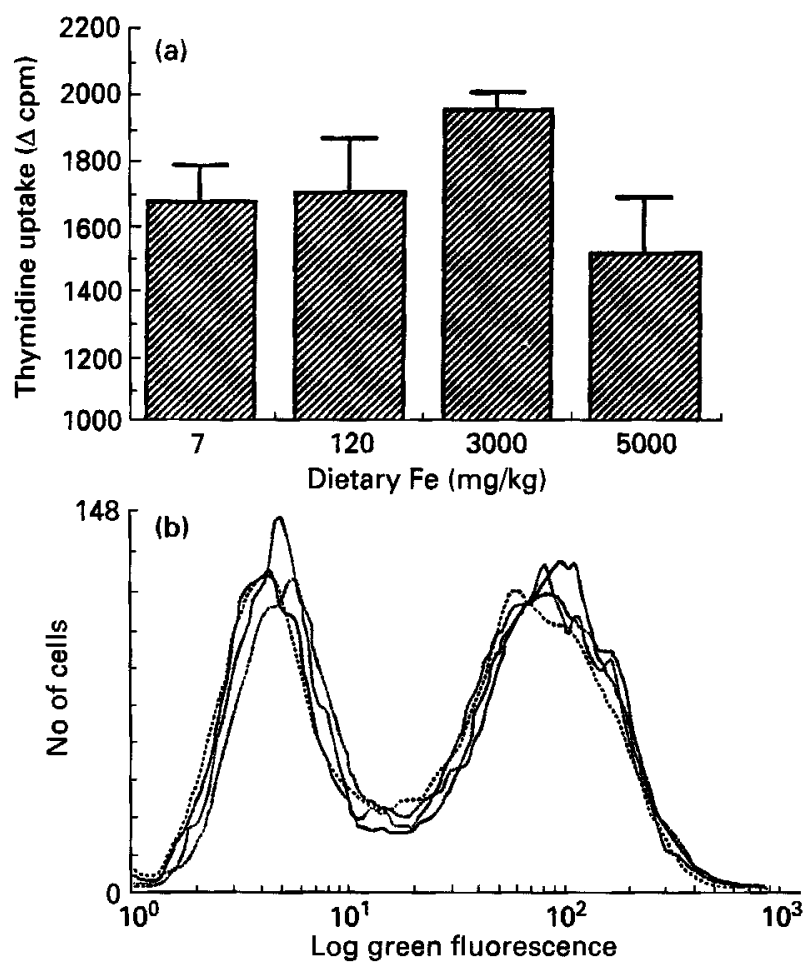

Fig. 4. (a) The antigen-presenting cell (APC) activity of spleen cells from male CBA/J mice fed on experimental iron diets to activate the SRBC-T-helper lymphocyte clone, (b) the anti I-A class II major histocompatibility antigen-staining splenic macrophages in Balb/c mice fed on $7 \mathrm{mg} \mathrm{Fe} / \mathrm{kg} \mathrm{(--),} 120 \mathrm{mg} \mathrm{Fe} / \mathrm{kg} \mathrm{(-...-)}$, $3000 \mathrm{mg} \mathrm{Fe} / \mathrm{kg} \mathrm{(-)} \mathrm{and} 5000 \mathrm{mg} \mathrm{Fe} / \mathrm{kg}$ (…) diets. (a) Values are means with their standard errors represented by vertical bars for twenty-four determinations in which a suspension of four pooled irradiated spleen cells per group were used, and (b) six pooled spleen cells per group were used. Mean values were not significantly different. For details of animals, diets and procedures, see p. 900 and pp. 902-903. cpm, Counts/min.

\section{DISCUSSION}

Studies were conducted to examine the effects of Fe on cellular immunity. Mice fed on the Fe-deficient diet had reduced responsiveness to CS and DTH stimulation compared with mice fed on a normal-Fe diet. The decreased CMI response in the Fe-deficient mice is consistent with clinical studies that reported a decreased skin-test response in Fe-deficient patients (Joynson et al. 1972; MacDougall et al. 1975) or a reduced CS response to DNFB in Fe-deficient mice (Kuvibidila et al. 1981). The influence of excess $\mathrm{Fe}$ in the diet was more complex. The high-Fe diets selectively depressed the CS response but had no effect on the classical DTH response. The depressed CS and normal DTH responses in the Fe-loaded mice are consistent with other reports in Fe-loaded human patients (Van Asbeck et al. 1982; Dwyer et al. 1987).

The effects of Fe deficiency and Fe supplementation on the CS and DTH responses suggest that the cellular immune alterations induced by Fe deficiency or excess Fe are not identical. The selective suppression of the CS by excess Fe without apparent alteration of the DTH response is consistent with the experimental evidence that the induction of the CS and DTH responses are not identical (Ray et al. 1983). Although both the CS and DTH responses are classified as CMI events, the induction of CS response, which is a clear-cut example of immunopathology, also requires the participation of $\mathrm{IgE}$ antibody molecules (Ray et al. 1983). It is probable that excess Fe selectively suppressed the CS response by 
altering the IgE antibody response that participates in the induction of the CS response without influencing the DTH response.

The mechanisms underlying the diminished responses, particularly the reduced DTH response in the Fe-deficient mice, are unknown. The reduced capacity of the primed spleen cells to transfer DTH response to naive normal mice suggested that an alteration in Tlymphocyte function was produced by Fe deficiency. However, the induction of a strong DTH response in Fe-deficient naive mice by normal primed spleen cells suggests that $\mathrm{Fe}$ deficiency did not alter the APC function. The decreased CMI response in the Fe-deficient mice appeared to be unrelated to IL-2 production because IL-2 secretion by spleen cells was unaffected by Fe deficiency. The substantial decrease in T-lymphocyte blastogenesis and INF- $\gamma$ production by spleen cells was consistent with the suppressed DTH or CS responses in the Fe-deficient mice. Previous observations indicate that addition of INF- $\gamma$ in vitro restores the depressed cytotoxic function of natural killer (NK) cells in Fe-deficient rats (Spear \& Sherman, 1992), which is consistent with the decreased INF- $\gamma$ production by spleen cells from Fe-deficient mice in the present study, since the diminished T-lymphocyte proliferation and INF- $\gamma$ production are important factors in the induction of DTH response and other forms of the CMI response. The validity of this assumption is based on the differential susceptibility of $\mathrm{T}_{\mathrm{H}} 1$ and $\mathrm{T}_{\mathrm{H}} 2$ helper lymphocyte subsets to Fe deprivation (Thorson et al. 1991). These cells participate in the respective CMI and humoral immune responses. The $\mathrm{T}_{\mathrm{H}} 1$ subsets are markedly sensitive to Fe deprivation. This may provide an explanation for the frequent observations of suppressed skin-test responses associated with Fe deficiency.

Modulation of the macrophage APC activity probably did not affect the immune responsiveness because the APC function of spleen cells and expression of the class II MHC surface antigen by the spleen cells were not affected by Fe deficiency or Fe overload. The results suggest that impairment of macrophage APC function does not account for the diminished CS and DTH responses in the Fe-deficient mice or the reduced CS response in the Fe-loaded mice. The macrophage as an APC also provides a co-stimulatory signal to antigen-MHC complex for the activation of T-helper lymphocytes (Weaver \& Unanue, 1990). Studies evaluating endotoxin-stimulated IL-1 production by macrophages in Fedeficient children (Bhaskaram et al. 1989) showed a normal IL-1 production. This also suggests that APC function is not altered by Fe deficiency.

The reduction in cellular immune competence by Fe deficiency may lead to an increased susceptibility of the host to infection or cancer. An increased incidence of urethan-induced lung tumours in mice fed on Fe-deficient diets has been reported (Omara \& Blakley, 1993). This observation is consistent with the depressed cellular immune response seen in the Fedeficient mice in the present study. The cellular immune response plays an important role in the production of urethan-induced lung tumours (Menard et al. 1973) and the DTH and cytotoxic lymphocyte responses which are involved in the suppression of tumour growth (Bhan et al. 1981).

In conclusion, the results of the present study indicate that Fe deficiency has a profound negative impact on cellular immunity. Fe deficiency is the most common mineral deficiency in the world: its victims number in the hundreds of millions (Van Eijk \& de Jong, 1992). Fe deficiency, therefore, could compromise the host resistance to a number of infections controlled by cellular immunity including tuberculosis, leishmaniasis, etc. Fe deficiency may also reduce the efficacy of vaccination programmes, particularly in developing countries. Excessive Fe supplementation, which also alters immune function, may also have a detrimental effect on the susceptibility to infectious disease, although on a worldwide basis Fe deficiency will undoubtedly have a greater impact. 
The authors owe special thanks to Jim Holmstrom, Department of Microbiology, and H. Hughes, Veterinary Infectious Diseases Organization, University of Saskatchewan, for technical assistance. This research was funded by the Natural Sciences and Engineering Research Council of Canada.

\section{REFERENCES}

Abbas, A. K., Lichtman, A. H. \& Pober, J.S. (1991). Cellular and Molecular Immunology. Toronto: W. B. Saunders Company.

Bhan, A. K., Perry, L. L., Cantor, H., McCluskey, R. T., Benacerraf, B. \& Greene, M. I. (1981). The role of T cell sets in the rejection of methylcholanthrene-induced sarcoma $\left(\mathrm{S} 1509_{\mathrm{a}}\right)$ in syngeneic mice. American Journal of Pathology 102, 20-27.

Bhaskaram, P., Sharada, K., Sivakumar, B., Rao, K. V. \& Nair, M. (1989). Effects of iron and vitamin A deficiency on macrophage functions in children. Nutrition Research 9, 35-45.

Blakley, B. R. \& Hamilton, D. L. (1988). The effect of iron deficiency on the immune response in mice. DrugNutrient Interactions 5, 249-255.

Bretscher, P. A. (1979). In vitro induction of delayed-type hypersensitivity. European Journal of Immunology 9 , $311-316$

Chandra, R. K. (1975). Impaired immunocompetence associated with iron deficiency. Journal of Paediatrics 86, 899-902.

Dovrak, H. F., Galli, S. J. \& Dovrak, A. M. (1986). Cellular and vascular manifestations of cell-mediated immunity. Human Pathology 17, 122-137.

Dwyer, J., Wood, C., McNamara, J., Williams, A., Andiman, W., Rink, L., O'Conner, T. \& Pearson, H. (1987). Abnormalities in immune system of children with beta thalassemia major. Clinical and Experimental Immunology 68, 621-629.

Flesch, I, \& Kaufmann, S. H. E. (1987). Mycobacteria growth inhibition of interferon- $\gamma$-activated bone marrow macrophages and differential susceptibility among strains of Mycobacterium tuberculosis. Journal of Immunology $138,4408-4413$.

Heinzel, F. P., Sadick, M. D., Holaday, B. J., Coffman, R. M. \& Locksley, J. (1989). Reciprocal expression of interferon- $\gamma$ or interleukin 4 during the resolution or progression of murine leishmaniasis: evidence for expansion of distinct helper T cell subsets. Journal of Experimental Medicine 169, 59-72.

Joynson, D. H. M., Walker, D. M., Jacobs, A. \& Dolby, A. E. (1972). Defect of cell mediated immunity of patients with iron deficiency anemia. Lancet ii, 1058-1059.

Kuvibidila, S. R., Baliga, B. S. \& Suskind, R. M. (1981). Effects of iron deficiency anemia on delayed cutaneous hypersensitivity in mice. American Journal of Clinical Nutrition 34, 2635-2640.

MacDougall, L. G., Anderson, R., McNab, G. M. \& Katz, J. (1975). The immune response in iron-deficient children: impaired cellular defense mechanisms with lateral humoral components. Journal of Paediatrics $\mathbf{8 6}$, 833-843.

Menard, S., Colnaghi, M. \& Cornalba, G. (1973). Immunogenicity and immunosensitivity of urethan-induced murine lung adenomata in relation to the host immunological impairment of the primary tumour host. British Journal of Cancer 27, 345-350.

Omara, F. O. \& Blakley, B. R. (1993). Influence of low dietary iron and iron overload on urethan-induced lung tumours in mice. Canadian Journal of Veterinary Research 57, 209-211.

Ray, M. C., Tharp, M. D., Sullivan, R. J. \& Tigelaar, R. E. (1983). Contact sensitivity reactions to dinitrofluorobenzene mediated by monoclonal IgE anti-DNP antibodies. Journal of Immunology 131, 1096-1102.

Smith, K. A. (1984). Interleukin 2. Annual Review of Immunology 2, 319-333.

Sorbie, J. \& Valberg, L. S. (1975). Iron balance in the mouse. Laboratory Animal Science 24, $900-904$.

Spear, A. T. \& Sherman, A. R. (1992). Iron deficiency alters DMBA-induced tumor burden and natural killer cell cytotoxicity in rats. Journal of Nutrition 122, $46-55$.

Thorson, J. A., Smith, K. M., Gomez, F., Naumann, P. W. \& Kemp, J. D. (1991). Role of iron in T cell activation: $T_{H} 1$ clones differ from $T_{H} 2$ clones in their sensitivity to inhibition of DNA synthesis caused by IgG mAbs against the transferrin receptor and the iron chelator desferrioxamine. Cellular Immunology 124, $126-137$.

Vadas, M. A., Miller, J. F. A. P., Gamble, J. \& Whitelaw, A. A. (1975). A radioisotopic method to measure delayed type hypersensitivity in the mouse. International Archives of Allergy and Applied Immunology 49, 70-92.

Van Asbeck, B. S., Vergrugh, H. A., Van Oost, B. A., Marx, J. J. M., Imhof, H. \& Verhoef, J. (1982). Listeria monocytogenes meningitis and decreased phagocytosis associated with iron overload. British Medical Journal 284, 542-544.

Van Eijk, H. H. \& de Jong, G. (1992). The physiology of iron, transferrin and ferritin. Biological Trace Element Research 35, 13-24.

Weaver, C. T. \& Unanue, E. R. (1990). The costimulatory function of antigen presenting cells. Immunology Today $11,49-55$. 